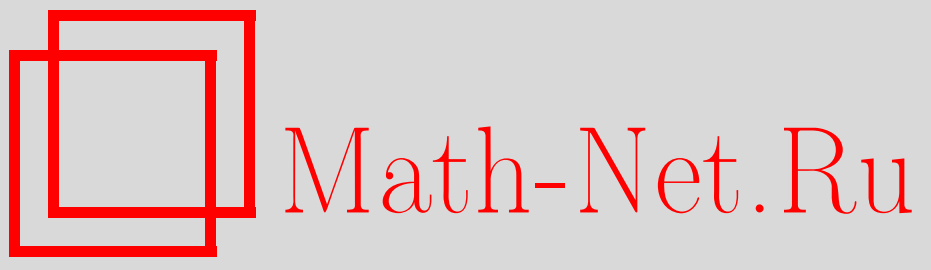

Общероссийский математический портал

В. В. Дубровский, Письмо в редакцию, Матем. заметки, 2000, том 67, выпуск 2, 320

DOI: https://doi.org/10.4213/mzm844

Использование Общероссийского математического портала Math-Net.Ru подразумевает, что вы прочитали и согласны с пользовательским соглашением http://www.mathnet.ru/rus/agreement 
Параметры загрузки:

IP: 3.82 .47 .9

26 апреля 2023 г., 14:51:45

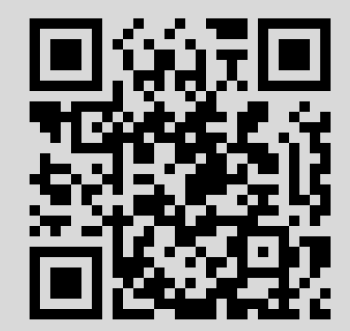




\section{ПИСЬМО В РЕДАКЦИЮ}

\section{В. В. Дубровский}

В работе "Регуляризованные следы несамосопряженных операторов" (Матем. заметки, 1999, т. 65 , № 5, с. 783-787) есть неточности:

a) теорема 5 верна при $\alpha \geqslant 2$, а не при $\alpha>1$, как утверждалось в статье;

б) пример в конце статьи для оператора $(-\Delta)^{\alpha}+P$ верен при $\alpha>3 / 2$, а не с $\alpha>1$.

С помощью аналитической теории чисел можно понизить степень $\alpha$ оператора Лапласа в последнем примере до $1 \frac{13}{80}$.

Магнитогорский государственный педагогический институт

Поступило 16.12.1999 